\title{
APPLICATION OF COAL THERMAL TREATMENT TECHNOLOGY FOR OIL-FREE FIRING OF BOILERS
}

\author{
B. Aliyarov, A. Mergalimova, U. Zhalmagambetova \\ Almaty University of Power Engineering and Telecommunications \\ 126 Baitursynov Str., Almati, 050013, KAZAKHSTAN \\ e-mail:kazresearch@mail.ru
}

The theoretical and practical introduction of this kind of firing boiler units in coal thermal power plants is considered in the article. The results of an experimental study of three types of coals are presented in order to obtain the required gaseous fuel.

The aim of the study is to develop a new, economically and ecologically more acceptable method for firing boilers at thermal power plants, which is able to exclude the use of expensive and inconvenient fuel oil.

The tasks of the experiment are to develop a technological scheme of kindling of boilers at thermal power plants, using as a type of ignition fuel volatile combustible substances released during the heating of coal, and to investigate three types of coal for the suitability of obtaining gaseous fuels, in sufficient volume and with the required heat of combustion.

The research methods include the analysis of technical and scientificmethodological literature on the problem of the present study, the study of the experience of scientists of other countries, the full-scale experiment on the production of volatile combustible substances.

During the full-scale experiment, the coal of 3 fields of Kazakhstan has been studied: Shubarkul, Maikuben and Saryadyr. The analysis has been performed and the choice of the most convenient technology for boiler kindling and maintenance of steady burning of the torch has been made according to the proposed method, as well as the corresponding technological scheme has been developed.

As a result of the experiment, it can be stated that from coal in the process of its heating (without access to oxygen), it is possible to obtain a sufficient amount of combustible volatile substances. The released gaseous fuel has the necessary parameters and is quite capable of replacing an expensive fuel oil. The resulting gaseous fuel is quite convenient to use and environmentally cleaner. The piloting scheme developed as a result of the experiment can be introduced in pulverized-coal thermal power plants, as a result of which they become single-fuel.

Keywords: boiler, coal, fuel oil, gas, ignition fuel, thermal power plants, volatile combustibles 


\section{INTRODUCTION}

The coal industry is one of the leading branches of the fuel and energy complex in many countries. Coal is used as a technological raw material (in the form of coke) in ferrous metallurgy and chemical industry (coke oven gas) for the production of mineral fertilizers and plastics, and coal is the energy source for electricity production at TPPs and for heating of dwellings. As a result of using coal, approximately $44 \%$ of the world's electricity is produced. In Kazakhstan, this figure is approximately $72 \%$ [1], [2].

As it is known, coal is much inferior to natural gas and oil for its own needs and especially for environmental performance. However, according to the estimates of the International Energy Agency [3], at the current consumption rates, the explored oil reserves will be depleted in 30 years, and gas - in the next 50 years (however, Kazakhstan has a more favourable prospect [4]), while coal reserves, with the most intensive use, will be sufficient for 200 years [5]. No one doubts today the need for the development of coal technologies. The remaining fuel resources will be enough for a much shorter period, and at the same time their cost is much higher.

According to the World Coal Institute [6], coal accounts for about $90 \%$ of the energy potential of all organic minerals suitable for the development of minerals. Prospects for the development of the world energy industry significantly depend on its resource availability. In this respect, the coal industry is in a much better position than the oil and gas industry, and therefore, in the long term, it is a more promising sector of the fuel and energy sector. For today's Kazakhstan, coal is the main fuel resource. The coal industry of Kazakhstan is one of the largest branches of the country's economy [7]. In terms of coal reserves, Kazakhstan is second only to China, the United States, Russia, Australia, South Africa and Ukraine. The state balance of Kazakhstan takes into account the reserves of 49 deposits amounting to 33.6 billion tons, including 21.5 billion tons of coal, and 12.1 billion tons of brown coal [8]. Most of the coal deposits are concentrated in the Central (Karaganda and Ekibastuz coal basins, as well as the Shubarkol field) and Northern Kazakhstan (Turgai coal basin), in southern Kazakhstan - Lenger and Nizh-Ili coals [5].

Among the CIS countries, Kazakhstan ranks second in terms of reserves and pre-bogs of coal, and takes the first place in terms of coal production per caput. The greatest volume of coal production in the republic falls on the Central (Karaganda) and North-Eastern (Pavlodar) regions - 96.2 \%. Kazakhstan's coal exports in 2003 amounted to 25.7 million tons with a total production volume of over 89 million tons [2]. At present, Kazakhstan is among the ten largest coal producers on the world market, as well as the top ten largest exporters. The republic gives about $3 \%$ of the world's coal exports. It should be noted that the need for coal will grow every year not only in Kazakhstan but also in the world as a whole. According to some data, in some developing countries the demand for coal will increase by $6 \%$ per year. The growth in the consumption of coal is caused by the need for numerous thermal power plants, which generate more and more electrical and thermal energy. Consequently, coal mining and development of new coal deposits will intensively increase. 


\section{THEORETICAL FRAMEWORK}

During the course of the research, the analysis of available sources (scientific literature and Internet resources) has been performed. The analysis has shown that the problem of replacing ignition fuel for another way is being investigated in many countries, including studies performed by scientists of the Republic of Kazakhstan, in particular on the use of plasma technologies for kindling of boiler units.

\subsection{Literature Review}

At the moment, all thermal power plants (TPPs) and large boiler plants that use natural gas and / or coal as the main fuel provide emergency and ignition fuel. As a rule, this fuel is fuel oil. Fuel oil, as fuel, has a number of unquestionable qualities: a high calorific value of $9500 \mathrm{kcal} / \mathrm{kg}$, a low ash content of $0.3-0.5 \%$, the possibility of obtaining a glowing flame (providing high radiation heat exchange in the furnace space), the possibility of organising certain conditions of burning in small (in size) furnaces. However, fuel oil, as fuel, has a number of serious shortcomings. Cocombustion of coal with fuel oil worsens the ecological and economic parameters of the boilers: the mechanical underfunding of fuel increases and the gross efficiency reduces (due to the increase in costs for own needs), the specific fuel consumption for the released electric energy increases, the high-temperature corrosion of the convective heating surfaces increases, the output of nitrogen oxides and sulfur (in the case of a higher sulfur content in fuel oil), there are emissions of carcinogenic vanadium pentoxide [7], [13]. The most significant drawback of fuel oil as a backup and pilot fuel is the inconvenience associated with its operation, caused by the multistage in the preparation of fuel oil for use [6]. Loading into tanks and subsequent unloading from tanks require its heating up to a state with acceptable fluidity, which, as a rule, is achieved through the use of water vapour. This means that at the points of loading and unloading of fuel oil it is necessary to have a source of steam with the required temperature. In addition to heating and mixing in tanks, it is also necessary to maintain the circulation of fuel oil throughout the entire path of its movement, from the storage to the injector, to provide, if necessary, the possibility of supplying fuel oil to the furnace. Therefore, the preparation of fuel oil for combustion is a complex and time-consuming process, in which it is necessary to ensure: a low (up to $3 \%$ ) water content in fuel oil, deep mixing of water with fuel oil, and necessary heating temperatures for fuel oil. Another important aspect is price; fuel oil is an expensive energy fuel.

All of the above-mentioned factors make the very urgent task of modern heat power engineering - the development of new technologies of oil-free firing of boilers at coal-fired TPPs.

One way of oil-free ignition of a coal torch at a TPP is to use plasma technologies. In [7]-[10], various technologies of fuel oil replacement at coal plants are considered, including methods of using plasma pilot burners for ignition of lowgrade fuels and anthracite. Plasma torches consist of a longitudinal chamber through which a dust-air mixture is fed into the boiler. Along the chamber, there are two rod 
electrodes, between which a powerful electric arc is excited by means of a movable plasmatron-igniter, which heats the incoming fuel-air mixture. The temperature of the gas jet at the exit from the plasma torch is $3500-5400{ }^{\circ} \mathrm{C}$. At this temperature, the thermal decomposition of coal and the inflammation of volatile substances take place rapidly, and, accordingly, the coke base ignites. When such a "prepared" mixture is supplied to the combustion chamber, a steady burning of the flame is ensured. However, the high temperature causes rapid wear of the rod electrodes, and frequent replacement is required. For the operation of a plasma torch, a water and air supply system is required, and a rather complex system of converting electrical energy into thermal energy is required. This complicates the design of the device and significantly increases the cost of installation.

Research [9] describes the development by the employees of the Institute of Combustion Problems (Almaty) and the Industry Centre for Plasma Energy Technologies of RAE UES of Russia. The research focuses on a new plasma-fuel system (PFS) for oil-free firing of boilers and for stabilising the combustion of a coal flare while reducing the amount of mechanical fuel burn-up and reducing the level of oxide formation nitrogen.

PFS technology is based on plasma thermo-chemical preparation of coal for combustion. It consists in heating the air mixture (coal dust and air) by electric arc plasma (at a temperature above $3000^{\circ} \mathrm{C}$ ). Due to gasification of fuel, a twocomponent mixture of combustible gases and coke is formed, which is easily ignited when it mixes with secondary air and stably burns without additional illumination with fuel oil. It is based on the technology of electrothermal-chemical fuel preparation (ETCPF). The essence of ETCPF (for low-reactive coal) consists in heating the air mixture to the temperature at which the most complete liberation of volatile $\mathrm{V}^{\Gamma \%} \%$ from coal dust is achieved and partial gasification of the coke residue is carried out in order to obtain a combustible mixture at the level of volatile, highly reactive coal. To reduce the energy consumption for processing, the flow of the air mixture entering the burner is divided into two unequal parts, with the heating of the smaller of them $(15 \%-20 \%)$, to the temperature of the complete release of volatile fuels (in the arcplasma zone) and partial gasification of the coke residue. As a result, a high potential ignition agent is formed that can initiate ignition and stabilise the combustion of a pulverized torch.

However, the way in which plasma technologies are used to kindle boiler units has a number of significant drawbacks that limit its use: high cost, limited plasmatron operating life, and energy costs.

It is suggested in [13] that natural gas (compressed or liquefied) is to be used to kindle boilers. Gas, as a fuel, has a number of advantages over fuel oil: an essentially simple technology of preparation for combustion and supply to the furnace (with sufficient heat of combustion), which significantly reduces the cost of own needs. But natural gas has relatively limited reserves compared to coal, and is not available in all regions of the country. The shortage of natural gas causes the development of solid fuel processing technologies to produce gaseous fuel, a natural gas substitute. 


\section{RESEARCH DESCRIPTION}

The Utility Model patent [14] shows the efficient, ecologically and economically more acceptable method of oil-free firing of the boiler units developed by the authors of the present research and the stabilisation of the flame burning. This technology is based on the use of gaseous fuels obtained from the thermal processing of coal. Figure 1 shows a possible technological scheme of oil-free ignition of the boiler, using combustible volatile substances as a fuel.

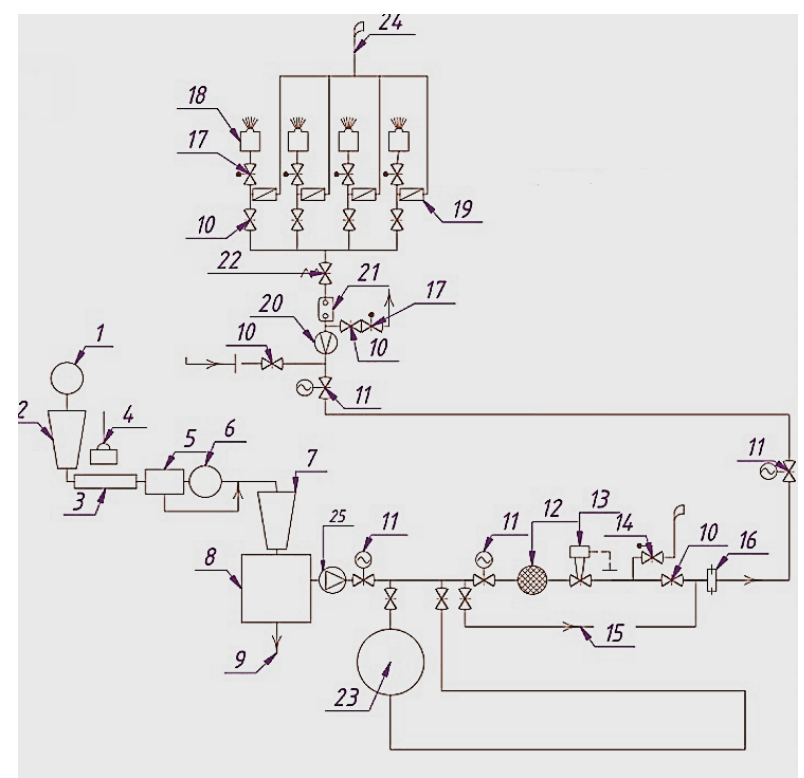

Fig. 1. Diagram of the technology of boiler firing with the use of combustible volatile substances.

1 - a car dumper, 2 - a receiving hopper, 3 - a belt conveyor, 4 - an electromagnetic separator, 5 - a vibrating screen, 6 - a hammer crusher, 7 - a raw coal bunker, 8 - a furnace for coal heating,

9 - an output of enriched coal mass, 10 - a gas stop valve, 11 - a gate valve with electric drive,

12 - a mechanical filter, 13 - a gas pressure regulator, 14 - a safety valve, 15 - a bypass line,

16,20 - a flow meter, 17 - a gas regulating valve, 18 - a gas burner, 19 - a cork valve,

21 - a high-speed gas valve, 22 - an asbestos damper regulator, 23 - a gas storage-receiver,

24 - safety candles, 25 - a fan.

The release of combustible volatiles is carried out in a special device (8), in which, without access to oxygen, the coal layer is heated. As a carrier of the initial thermal energy necessary for heating coal, steam can be used, in the presence of a working boiler; electricity or other medium of thermal energy. The combustible volatile substances released after heating $\left(\mathrm{CO}, \mathrm{H}_{2}, \mathrm{CH}_{4}\right.$ and others) in the case of kindling are directly fed to the boiler burners (18), after ignition they can accumulate in a special gas storage tank (23), at a certain pressure and in the future used to stabilise the combustion of the torch.

This process of obtaining volatile fuels from coal is not a process of coal gasification. Gasification technologies [15]-[18] are more complex and expensive. However, the process in question differs from the processes of high-temperature pyrolysis [14] and gasification in that the heating is carried out only up to the 
temperatures required for the release of combustible volatile substances in the required volume and with sufficient heat of combustion, which depends on the charcoal characteristics.

In order to produce gaseous fuels capable of replacing fuel oil at pulverized coal plants, we have experimentally investigated three types of solid fuels, whose deposits are located in Kazakhstan: brown coal Maikubenskoe, brown coal Shubarkulskoye and brown coal Saryadyrskoye. The composition of the samples of the coal [1], [11] (on the working mass) and the value of analytical moisture are presented in Table 1.

Table 1

Composition and Analytical Moisture of Coal Samples

\begin{tabular}{|l|c|c|c|}
\hline \multirow{2}{*}{ Element } & \multicolumn{3}{|c|}{ Element content in mass \% } \\
\cline { 2 - 4 } & $\begin{array}{c}\text { Black coal } \\
\text { Shubarkulskoe }\end{array}$ & $\begin{array}{c}\text { Brown coal } \\
\text { Maikubenskoe }\end{array}$ & $\begin{array}{c}\text { Brown coal } \\
\text { Saryardyrskoe }\end{array}$ \\
\hline $\mathrm{C}$ & 76.9 & 73.52 & 40.71 \\
\hline $\mathrm{H}$ & 5.35 & 5.0 & 2.66 \\
\hline $\mathrm{N}$ & 1.48 & 1.0 & 0.39 \\
\hline $\mathrm{O}$ & 15.3 & 6.3 & 6.56 \\
\hline $\mathrm{S}$ & 0.5 & 0.67 & 0.27 \\
\hline A & 9.27 & 13.51 & 46.47 \\
\hline $\begin{array}{l}\text { Analytical } \\
\text { moisture } \\
\text { content, } \%\end{array}$ & 14.25 & 7.11 & 2.94 \\
\hline
\end{tabular}

Experimental studies of the process of obtaining combustible gaseous substances from coal have been carried out on a hardware complex, the structural diagram of which is shown in Fig. 2.

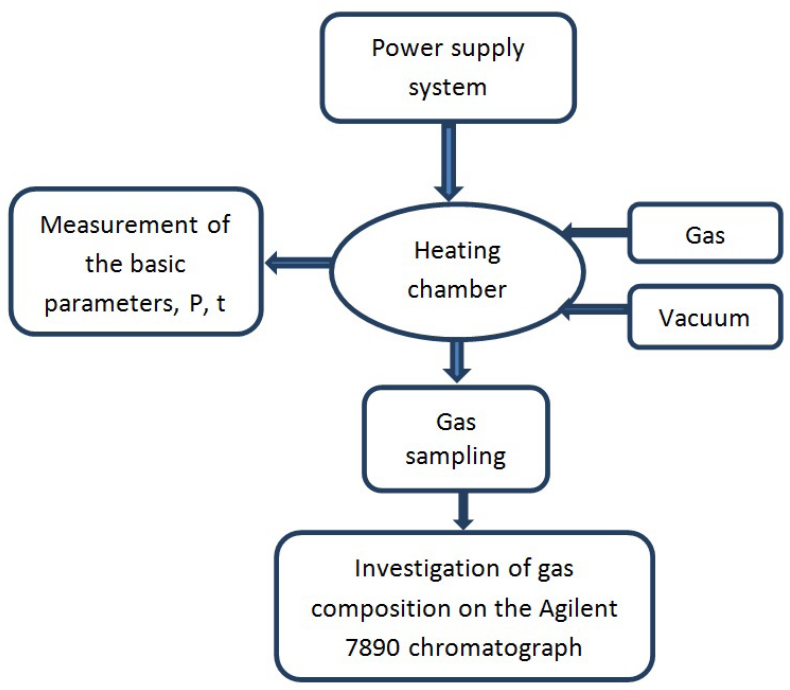

Fig. 2. Structural diagram of installation. 
A pre-treated coal sample (a particle of about $5 \mathrm{~mm}$ in size) has been placed on a substrate in an experimental chamber (Fig. 3). Then a smooth increase in voltage has been carried out. As a result of voltage increase and temperature increase, the process of thermal destruction of the sample begins, thereby initiating the sublimation of volatile compounds, after which heating is continued while maintaining a constant voltage level, by adjusting the current.

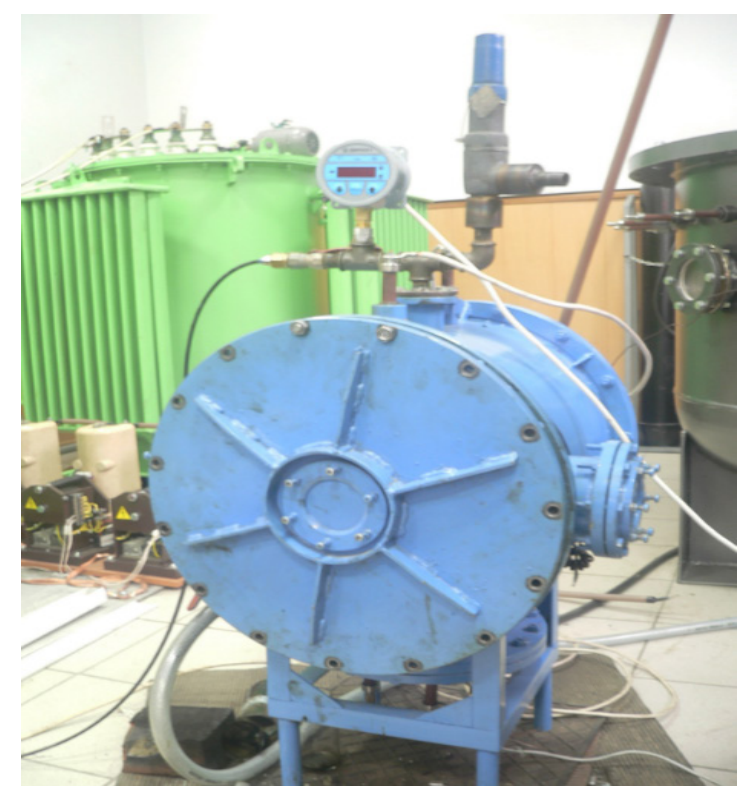

Fig. 3. Experimental installation chamber.

The experiments have been carried out in a nitrogen atmosphere at a given pressure not exceeding the permissible maximum chamber pressure.

In the course of the experiment, the temperature dynamics at certain points of the sample are measured to construct patterns of the dynamics of the thermal field. During and after the completion of the experiment, gas samples from the chamber are sampled and analysed. Sampling of gas is made directly from the chamber and through polymer pneumatic hose is fed to the filter regulator LFR-1/4-D-5M-MINI. This device allows taking a gas sample without affecting the pressure in the chamber, and also removes the aerosol phase and dust particles from the gas. After the filter regulator, the gas flows to the Agilent 7890 chromatograph, which analyses the resulting gas.

The duration of the experiment has been limited to reaching a set maximum temperature of $600{ }^{\circ} \mathrm{C}$.

Tables 2 and 3 demonstrate the results of experimental studies to determine the quantitative composition of the gas obtained from the coal samples of the various deposits presented above.

Figure 4 shows the dependence of the yields of the main combustible gas components $\left(\mathrm{CO}, \mathrm{H}_{2}, \mathrm{CH}_{4}\right)$ on the temperature in the range of $300-600{ }^{\circ} \mathrm{C}$, and Table 2 demonstrates their total yields. 
The Total Yield of Combustible Gas Components (CO, $\left.\mathrm{H}_{2}, \mathrm{CH}_{4}\right)$ in the Temperature Range of $300^{\circ} \mathrm{C}-600{ }^{\circ} \mathrm{C}$

\begin{tabular}{|l|c|c|c|c|}
\hline \multirow{2}{*}{$\begin{array}{l}\text { The deposit of coal } \\
\text { samples }\end{array}$} & \multicolumn{3}{|c|}{ Total yield $\mathbf{C O}, \mathbf{H}_{2}, \mathrm{CH}_{4}(\%)$ depending on the heating temperature , ${ }^{\circ} \mathbf{C}$} \\
\cline { 2 - 5 } & 300 & 400 & 500 & 600 \\
\hline Shubarkul & 1.2 & 4.56 & 12.32 & 18.71 \\
\hline Maikuben & 0.9 & 3.22 & 8.41 & 10.85 \\
\hline Saryadyr & 0.5 & 2.13 & 5.2 & 6.70 \\
\hline
\end{tabular}

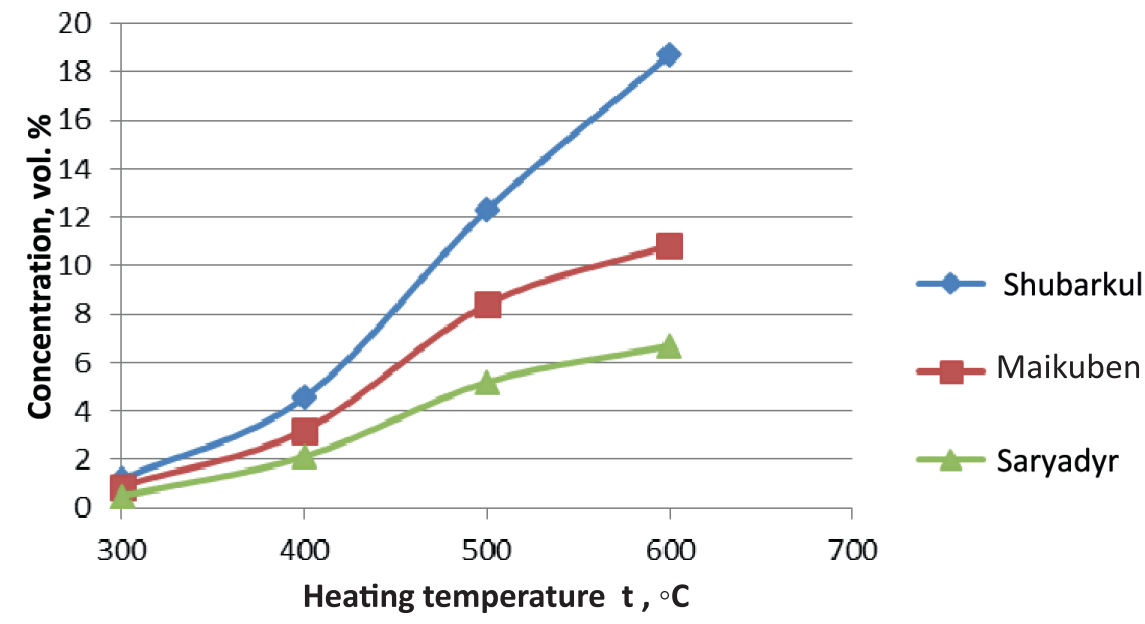

Fig. 4. Dependence of the output of combustible gas components $(\mathrm{CO}, \mathrm{H} 2, \mathrm{CH} 4)$ on the heating temperature.

Based on the results of the experiments performed, it is evident that with increasing temperature of heating of coal samples in the range of $300{ }^{\circ} \mathrm{C}-600{ }^{\circ} \mathrm{C}$, volumetric concentrations of combustible gas components increase. The composition of the gas also changes significantly with an increase in temperature. Table 3 shows the composition of the gas obtained from the Shubarkul stone long-flame coal.

Table 3

Composition of Gases from the Shubarkul Long-flame Coal

\begin{tabular}{|l|c|c|c|c|c|c|c|}
\hline $\begin{array}{l}\text { Heating } \\
\text { tempera- } \\
\text { ture t, }{ }^{\circ} \mathrm{C}\end{array}$ & $\mathrm{CO}_{2}+\mathrm{H}_{2} \mathrm{~S}$ & $\mathrm{CO}$ & $\mathrm{C}_{\mathrm{m}} \mathrm{H}_{\mathrm{n}}$ & $\begin{array}{c}\mathrm{CH}_{4} \text { and } \\
\text { homology }\end{array}$ & $\mathrm{C}_{2} \mathrm{H}_{6}$ & $\mathrm{H}_{2}$ & $\mathrm{~N}_{2}$ \\
\hline 300 & 18.2 & 9.0 & 11.3 & 21.2 & 30.1 & 6.3 & 3.9 \\
\hline 400 & 14.4 & 8.4 & 9.6 & 31.6 & 21.2 & 10.4 & 4.4 \\
\hline 500 & 6.2 & 6.2 & 4.6 & 40.3 & 14.4 & 24.8 & 5.7 \\
\hline 600 & 5.0 & 5.2 & 2.2 & 41.4 & 6.8 & 34.3 & 6.2 \\
\hline
\end{tabular}


Based on the results of determining the quantitative composition of the gas presented in Table 3, it can be concluded that with an increase in the heating temperature, the yield of carbon dioxide $\mathrm{CO}_{2}$ decreases, which favourably affects the heat of combustion of the gas, and the yield of $\mathrm{CH}_{4}$ increases. An increase in the yield of resinous substances is also observed, especially in the coal of the Shubarkul field, which is long-flame.

The results of calculating the heat of combustion, the produced gas from the presented samples of coal at different heating temperatures have shown that with increasing temperature of heating, the heat of combustion of combustible gases obtained from coal samples also increases. In all considered coal samples, the maximum value of the heat of combustion can be traced at a heating temperature of $600{ }^{\circ} \mathrm{C}$. The greatest value is observed in the coal of the Shubarkul field - 29.1 MJ $/ \mathrm{m} 3$, and the minimum value for brown coal of the Saryadyr field is $13.5 \mathrm{MJ} / \mathrm{m} 3$.

Based on the results of experimental studies, it is possible to conclude that from the three samples of coal presented for the production of combustible gas, the coal of the Shubarkul and the coal of the Maikuben deposits are most suitable. For use in the boiler as a pilot fuel, it is sufficient to heat the coal to temperatures of $350-450{ }^{\circ} \mathrm{C}$. The resulting flammable gas, at relatively low heating temperatures, is released in the required volume and has a sufficient heat of combustion to be used in the process of firing boiler units, thereby replacing the expensive and difficult fuel oil.

\section{CONCLUSION}

The analysis of the results of this stage of the study has shown that the issue of replacing ignition fuel at pulverized coal plants is relevant. Based on the results of experimental studies, the authors of the present research can conclude that it is possible to obtain gaseous fuel from coal, with the necessary parameters for combustion in boilers.

The next stage of the research is the analysis of the influence of the fuel replacement technology on the emissions of sulfur, nitrogen, and vanadium dioxide oxides released during the combustion of fuel oil. On the basis of this technology for the production of volatile combustible substances, the further research will also be devoted to the investigation of the possibility of using them in small boilers designed to supply thermal energy to small settlements. In this case, it is possible to supply this settlement with three types of energy: electric, heat and gas fuel for domestic needs.

As a result of the research, it can be stated that the proposed method of oil-free firing of boiler units with combustible volatile substances allows excluding the use of fuel oil or natural gas to kindle the boiler and maintain a stable ignition of the pulverized flame, while operating the boiler with reduced loads. This gives a significant reduction in financial costs associated with the high cost of fuel oil. Energy costs for the plant's own needs are also reduced, due to the multi-stage preparation of fuel oil for incineration. The efficiency of boiler units is improved. 


\section{REFERENCES}

1. Dukenbayev, K.D. (1995). Energetics of Kazakhstan (vol. 1). Almaty: Gylym.

2. Aliyarov, B.K., \& Aliyarova, M.B. (2010). Kazakhstan: Energetic security, energetic efficiency and energy development stability. Almaty: Gylym.

3. International Energy Agency (1994). World Energy Outlook. Available at http://www. worldenergyoutlook.org/media/weowebsite/2008-1994/weo1994.pdf

4. Nadirov, N.K. (1995). Oil and gas of Kazakhstan. Almaty: Gylym.

5. Chokin, Sh.Ch., Sartayev, T.S., \& Shkret, A.F. (1985). Energetics and electrification of Kazakhstan (vol. 1). Almaty: Nauka.

6. Aliyarov, A.B., Aliyarov, B.K., \& Aliayrova, M.B. (2016). Supply of thermal energy in Kazakhstan (features, experience, problems). Almaty: LEM.

7. Karpenko, E.I., Messerle, V.E., \& Konokhov, N.M. (2010). Plasma-Energy technologies of coal use for effective replacement of fuel oil and natural gas in the fuel balance of TPPs. Thermal Energy, 10, 53-60.

8. Messerle, A. V., Messerle, E., \& Ustimenko, A. B. (2017). Plasma thermochemical preparation for combustion of pulverized coal. High Temperature, 55(3), 352-360.

9. Messerle, V., Ustimenko, A., \& Lavrichshev, O. (2016). Arc plasma thermochemical preparation of coal to effective combustion in thermal power plants. International Journal of Energy and Power Engineering, 3(11).

10. Dubrovsky, V.A., \& Zubova, M.V. (2012). Energy-saving systems of kindling and lighting of a torch of combustion chamber of boilers. Krasnoyarsk: Siberian Federal University.

11. Verbovetsky, E.H., \& Kotler, V.R. (1984). Replacement of fuel oil with coal at the kindling and illumination of a torch in pulverized-coal boilers. Energo-Economy Abroad, $1,16-17$.

12. Yermagambet, B.T., \& Kasenov, B.K. (2013). Clean coal technologies: Theory and practice. Karaganda: TENGRI Ltd.

13. Aliyarov, B.K., \& Mergalimova, A.K. (2017). On the advantages of using gas to kindle boiler units. Proceedings of the 1st International Scientific and Practical Conference "Modern Trends in Boiler Building”, Barnaul.

14. Aliyarov, B.K., \& Mergalimova, A.K. (2017). The method of oil-free firing of boiler units. Patent for Utility Model No. 2450. State Register of Utility Models of the Republic of Kazakhstan.

15. Zhang, D. Thermal Decomposition of Coal. Coal, Oil Shale, Natural Bitumen, Heavy Oil and Peat, 1. Encyclopaedia of Life. Available at http://www.eolss.net/sample-chapters/ c08/E3-04-03-02.pdf

16. Messerlea, V.E., \& Ustimenko, A.B. (2016). Plasma gasification of coal with the extraction of valuable components of the mineral mass. Engineering \& Technologies, 9(8), $1311-1313$

17. Zhao, Y., \& Wang, S. (2017). Analysis of thermoelectric generation characteristics of flue gas waste heat from natural gas boiler. Energy Conversion and Management, 148, 820-829

18. Reid, D., Cabe, J.E., \& Bearden, M.D. (2010). PNNL coal gasification research. Richland, WA: Pacific Northwest National Laboratory. 


\title{
AKMEN̦OGḶU TERMISKĀS APSTRĀDES TEHNOLOGIJAS \\ PIELIETOŠANA APKURES KATLOS BEZ ŠKIDRĀ KURINĀMĀ IZMANTOŠANAS
}

\author{
B. Alijarovs, A. Mergalimova, \\ U. Žalmagambetova
}

Kopsavilkums

Šajā rakstā aplūkota teorētiska un praktiska apkures katlu agregātu ieviešana akmeņogḷu termoelektrostacijās. Eksperimentālā pētijuma rezultāti par trīs veidu oglēm ir paredzēti, lai iegūtu vajadzīgo gāzveida kurināmo.

Pētījuma mērḳis ir izstrādāt jaunu, ekonomiski un ekologiski pieņemamāku metodi apkures katlu izmantošanai termoelektrostacijās, lai nebūtu jāizmanto dārgās un neērtās degvielelıılas.

Eksperimenta uzdevums ir izstrādāt katlu sildīšanas tehnologisko shēmu termoelektrostacijās, izmantojot og̣̣u sildīšanas laikā izdalītās degošās vielas. Izpētītas trīs veidu ogles, lai iegūtu pietiekamu daudzumu gāzveida kurināmā, un ar vajadzīgo sadegšanas siltumu.

Pētījuma metodes iekḷauj tehniskās un zinātniski-metodiskās literatūras analīzi par pētījuma problēmu, citu valstu zinātnieku darba pieredzes analīzi; gaistošu degošu vielu pilna apjoma ražošanas eksperimentu.

Eksperimenta laikā tika pētītas Kazahstānas ogles trīs dažādās ieguves vietās: Šubarkuḷā, Maikubenā un Sariadirā. Tika veikta analīze un izvēelèta visērtākā tehnologija katlu uzkarsēšanai un deg̣̣a vienmērīgas degšanas uzturēšanai saskaņā ar izstrādāto metodi, kā arī piedāvāta atbilstoša tehnoloğiskā shēma.

Eksperimenta rezultātā var secināt, ka no oglēm to sildīšanas procesā (bez pieejas skābeklim) ir iespējams iegūt pietiekamu daudzumu degošu gaistošu vielu. Atbrīvotajai gāzveida degvielai piemīt nepieciešamie parametri, un tā var aizstāt dārgo mazutu. Iegūtā gāzveida degviela ir ļoti ērta lietošanā un videi draudzīgāka. Eksperimenta rezultātā izstrādāto pilotprojektu var ieviest pulverizētās ogles termoelektrostacijās, kā rezultātā tās izmanto vienu degvielas veidu.

06.03.2018 